\title{
Teaching Sustainability via Smartphone- Enhanced Experiential Learning in a Botanical Garden
}

\author{
http://dx.doi.org/10.3991/ijim.v8i1.3441
}

\author{
H. Meishar- Tal ${ }^{1,2}$, M. Gross ${ }^{2}$ \\ 1 The Open University of Israel, Tivon, Israel \\ ${ }^{2}$ Oranim College, Tivon, Israel
}

\begin{abstract}
This paper presents findings from an evaluation study of a project aimed at using smartphones for experiential learning in the botanical garden by pre-service teachers. The evaluation of the project focused on four main aspects: the teaching students' and the instructor's general satisfaction with the project, the students' perception of the contribution of the project to their learning, the students' perception of the contribution of the smartphone to the learning process, and the quality of their learning outcomes, e.g., the Smartphone-enhanced experiential learning activities that they designed. This initial attempt to integrate experiential learning and smartphones elicited many important conclusions about how the smartphone may be integrated into experiential learning
\end{abstract}

Index Terms - Sustainability, Mobile learning, Smartphones, Outdoor learning, experiential learning, extramural learning.

\section{INTRODUCTION}

This The use of Smartphones for learning purposes generally, and for experiential learning particularly, is controversial among educators. Many educators would prohibit students' use of cellular telephones even in learning contexts in order to defeat the instruments' distractive effect on them [1]. Others, however, see enormous potential in personal mobile technologies for the enrichment of learning and the expansion of fascinating experiential and investigative learning opportunities [2] [3].

This article presents findings from a study that tracked an attempt to train teaching students in the development of smartphone-enhanced experiential learning activities in the botanical garden of Oranim Academic College of Education in Israel. The study probed the students' attitudes toward integrating the smartphone into teaching and their ability to develop activities that combine experiential learning and smartphone use.

\section{THEORETICAL BACKGROUND}

To develop technology-enhanced learning activity, teachers need to acquire a set of skills and knowledge. Koehler and Mishra [4] list three core components of knowledge that a teacher must acquire in order to teach effectively with technology: knowledge of the technology itself (including familiarity with it and its potential as a pro-learning tool), of pedagogy (knowing how to teach effectively), and of content (expertise in the subject matter being taught). The three bases overlap, meaning that the teacher needs the ability to integrate them: the context of the specific content, appropriate pedagogy, and support from suitable technology.

Adapting Koehler and Mishra's Tpack model to the teaching of sustainability via experiential learning combined with the use of cellular telephones, we may align the development of such a task in accordance with the three bases of knowledge as follows (Figure1):

a. the content - sustainability;

b. the pedagogy - experiential learning;

c. the technology - optimal use of Smartphones and their potential in the service of learning.

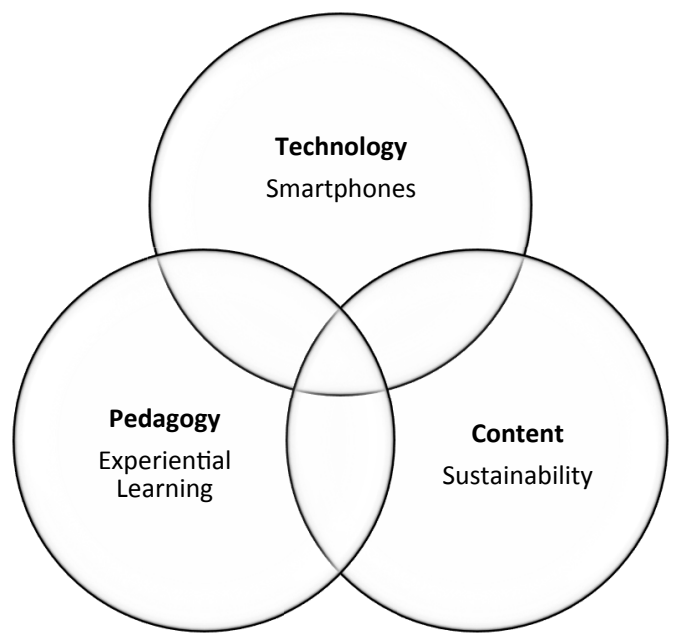

Figure 1. The Pedagogical model (Based on Tpack)

Below we expand on each of these bases of knowledge:

\section{A. Sustainability}

Sustainability is a worldview that advocates long-term sound functioning of society in its natural environment in the realization that all of us share the web of life on Earth. Sauve [5] defines the "environment" as a shared resource for both economic development and the sustenance of life. If so, the goal in sustainability education is to promote economic development, social equality, and ecological sustainability concurrently. 
Extramural learning, specifically in a natural environment eases the way to adventures in the environment, strengthens the connection with nature, and whets one's commitment and desire to preserve nature [6]. Hence the importance of learning in a natural environment in the teaching of sustainability, especially among those of young age [7].

\section{B. Experiential learning}

Experiential learning is a process that creates knowledge as the outcome of an experience combined with abstract understanding. According to Kolb [8], meaningful learning takes place by means of concrete experience in a four-phase cyclical process: (a) concrete experiencing of the environment/phenomenon; (b) reflective observation of the experience, (c) generalization and conceptualization on the basis of the reflection, and (d) active experimentation, i.e., development of an investigative/creative act in accordance with the initial experience.

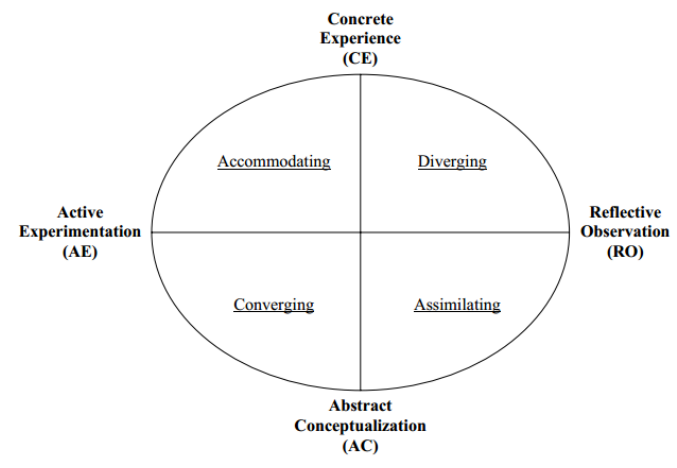

Figure 2. . The Experiential Learning Cycle ( Kolb, 1986).

Kolb's model (Figure 2) serves as a basis for the development of learning activities in class and, especially, away from class [9] in locations that set up an encounter with the concrete environment. Learning in a botanical garden is a natural gateway to experiential learning of this kind.

\section{Mobile learning}

Mobile learning is learning that avails itself of mobile technologies, i.e., laptop computers, tablets, and cellular telephones [10]. Mobile devices have enormous teaching and learning potential in both intramural and extramural settings. They may enrich learning by providing conditions for authentic contextual learning [11]. Learning by means of mobile instruments can be spontaneous and guided by needs, since the instruments are in our possession everywhere and at all times. They defy constraints of time and place; the only limits to their use are signal constraints-places where signal is not yet available — and battery life.

The use of mobile instruments has been shown able to whet learners' motivation [12]. More than this, however, it may be supportive of learning activities themselves. It can serve goals that range from gathering local content to creating and disseminating knowledge straight from the field. It helps the learner access information from any source, at any time.
Smartphones, unlike their predecessors, can serve as measurement tools by means of specific applications (e.g., a distance meter or a compass). They can be used to document information in the field due to their built-in cameras and audio recorders. They can even be used for navigation with their built-in GPS and maps [2].

The combination of experiential learning and mobile technology, however, poses a singular challenge. The integration of experiential learning and mobile technologies into learning activity has to be carried out in such a way that the use of the mobile technologies will not impair the experiential adventure [13]. That is, one must avoid a situation in which learners receive information from their mobile devices instead of learning from their experience in the field. Mobile technologies should be used in a way that will focus the learner on the learning environment; the instruments should be used intelligently, for the purpose of broadening the learner's capabilities and abetting an active learning experience as opposed to substituting for it. Namely, the technology should serve as a medium for the exploration, not just the study, of the environment outside the classroom.

\section{THE WANDERING PLATFORM}

The Wandering platform (Figure 3) was developed as a place to manage learning within a mobile learning setting. It allows users to store learning activities ("stations") and access them from any smartphone. Those who develop Wandering stations receive a password that lets them manage a personal or shared database of stations that users in the field can access by scanning an appropriate $\mathrm{QR}$ code or using a GPS-based service. When the code is scanned, users receive on their telephone screen an assignment that includes a practical task and the possibility of information feeds (responses) of various types - closed questions, open questions, or uploading of files (including picture files).

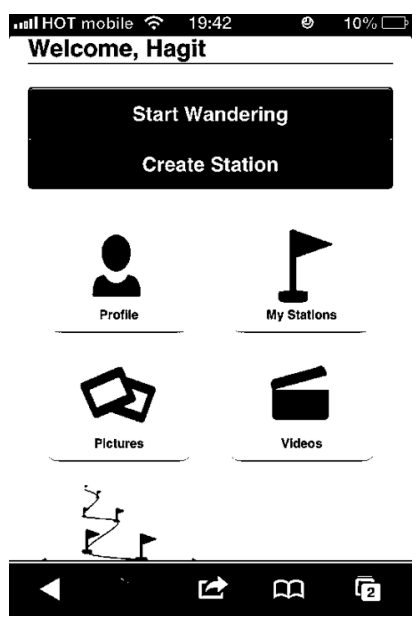

Figure 3. Wandering Interface

The platform allows users to re-use tasks stored in the database in a modular manner and to create study/teaching units that combine several stations.

\section{CASE STUDY}

The course, titled "Environmental Thinking," imparts initial concepts and principles of sustainability. In the 
teaching of sustainability, learning through an experiential approach that exploits the resources of the natural environmental is immensely important. At Oranim College, where the activity took place, learners are able to visit a botanical garden that offers abundant opportunities for encounters with the theme of sustainability in an adventuresome, experiential way that engages all the senses: vision, hearing, taste, smell, and touch.

The plan was to let students in the course develop smartphone-enhanced experiential activities throughout the botanical garden for a final target population composed of random visitors to the garden. This means that the activities should have been of the sort that do not require a teacher's mediation and can be carried out independently and in a modular way by playing with smartphones among sites marked with QR codes. Another requirement was that the tasks be suitable for all seasons of the year and be based on experiential learning within the confines of the garden.

The course took place in the first semester of the 2012/13 academic year. Fifteen students were enrolled. Four lessons toward the end of the course were devoted to a workshop in the garden. The first was pledged to the initial experiencing of a mobile learning activity in which the Wandering platform took part. The students were given a set of activities on soil erosion. At the end of the activity, they were given various sites (stations) around the garden, for which they were to develop learning activities on various topics associated with sustainability (compost, land cover, attraction of butterflies in the garden, etc.).

In the second lesson, the students continued to design the stations. At its end, they uploaded the stations to the Wandering learning management platform. In all, they developed seventeen mobile experiential learning activities at six different locations in the garden.

In the third lesson, the students implemented their activities; the group passed all the stations that all members had created and followed each activity with peer feedback.

In the fourth lesson, a game using the stations that had been prepared was played, the students assuming the role of a random visitor. Finally, the overall concept was presented and the possibility of creating diverse lesson plans using a play-acting approach, constructed from the collection of activities that had been prepared at the stations, was described.

\section{Methodology}

The workshop was complemented by evaluation research that examined it from four standpoints:

1. students' evaluation of the learning activity at the workshop;

2. students' willingness to apply the knowledge they had acquired to the future use of mobile technologies in experiential learning;

3. the extent of smartphone use at the workshop.

4. the quality of the students' designed smartphonebased experiential learning activities;

The research tools available to the researchers were a summarizing feedback questionnaire administered at the end of the activity and an analysis of the students' products (activities). In all, seventeen mobile experiential learning activities were developed in the course at six different locations (stations) in the botanical garden.

\section{FINDINGS}

\section{A. Students' evaluation of the learning activity}

In the summarizing questionnaire, the students were asked to describe, in their own words, what the workshop contributed to them in various respects: development of thinking skills, development of skills related to the planning of teaching activity in the field, sustainability studies, and technological skills.

The responses showed that the students thought the workshop contributed to the development of thinking skills. They stressed, however, that it accomplished this not due to the use of the cellular telephone but due to the planning of learning activities.

As for technological skills, the activity was not perceived as having imparted them. One of the students did note, "I learned the QR code application and how to enter the stations into the computer and correct them." Another student, however, clarified, "You already have to have basic skill, so from this standpoint I don't think there was much to learn."

The value of the activity found expression in the development of skills related to the planning of experiential learning activity in the field. "To write the activities," one student wrote, "we had to think broadly and be mindful of the limitations of the terrain/flora/seasonal changes. The task should be broad and not dependent on time and season." The value of the activity was also interpreted in terms of difficulty: "I discovered that it's hard. The main difficulty was to get everyone to understand the station that I prepared. Simple words and a task suitable for everyone."

Additional difficulties that students mentioned in the summarizing phase of the course concerned technical problems that they had encountered during the activity. "The site jammed quite a bit," one student said. Others cited miscellaneous hardships: short battery life, signal problems, inconvenience in reading the telephone screen, and difficulties in operating the phone.

\section{B. Students' willingness to apply the knowledge they had acquired in the future}

In the summarizing questionnaire, the students were also asked about their post-activity attitude toward the use of smartphones in extramural learning activity. Here they were of more than one mind. About half felt that the adventure in the botanical garden turned them in favor of using smartphones: "At the beginning of the task, I maintained that when you head into nature you have to feel it via your hands and feet. After the adventure, I found that there's room to fit smartphones into the activity." Also: "Before the activity, I felt an aversion to the use of smart mobile instruments, but now I see the advantages (dynamism, the possibility of using a camera, it records, you can check it right away...)." Contrarily, one student argued, "I still that think you can learn without smartphones even today and that learning with a facilitator is better." Several ambivalent responses were offered: 'I'm still 'stuck' in the old days; it's hard for me to make room for cellular teaching, but I don't rule it out, either. I think it might work nicely with certain populations and appropriate ages.", 
Finally, the students were asked whether they would recommend that their friends take part in a similar workshop in the future. Six of the students answered in the negative and eight in the affirmative. When asked whether they thought they would use the knowledge that they had acquired in the workshop in teaching their classes, three replied in the negative and eleven in the affirmative.

The findings imply that for some of the students the need of using the mobile phone for experiential learning was not convincing enough. They couldn't grasp the advantages of using the smartphones in the botanical gardens. The reasons for this may be related to the characteristics of the students in the group, who were mostly of teaching preschool, the design of the course and the chosen platform, as will be discussed in the next paragraph.

\section{Contribution of the Smartphone to experiential learning (extent of use)}

The last question concerned the students' attitude toward the contribution of the cellular phone after they took the course. The students were given a closed question asking them to rank the Smartphones' contribution in various respects: its use as a way to document findings and measure phenomena, its use as a navigational device and a way to receive instructions, and, finally, its use as a way to generate learning motivation and support organization and order. Figure 4 reports the average responses.

The figure shows that the students did not rate the contribution of using cellular telephones in the botanical garden as high in any indicator. They perceived the smartphone as making a medium to strong contribution in documenting findings and accessing instructions and a very small contribution to orientation in the garden and measurement of phenomena. By implication, the potential contributions of the cellphone to meaningful experiential learning were not fully utilized in this activity. If so, the integration of these instruments into learning activity and the efficiency of the Wandering platform as a venue for mobile learning need to be rethought.

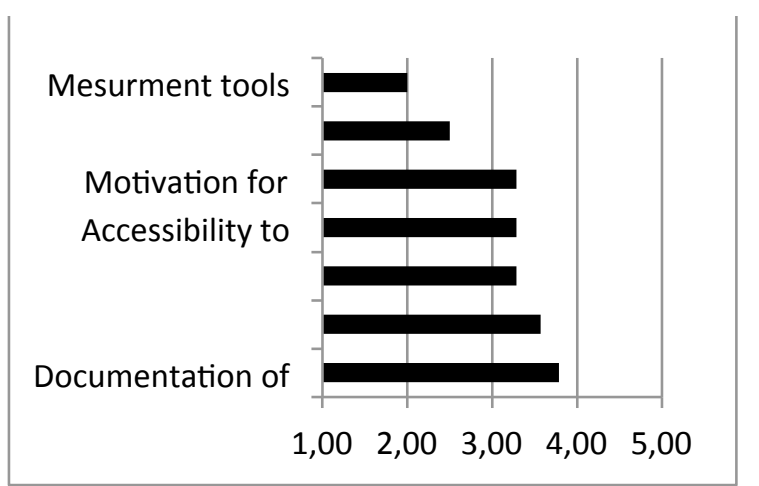

Figure 4. Contribution of the Smartphone to Learning in the Botanical Garden

\section{Quality of students' activities}

The students set up seventeen stations for activities at six different locations in the garden.

The table below summarizes the researchers' evaluations of various activities in four respects: phrasing of the instructions (clarity, modularity), engagement of the senses, phases of the task following Kolb's model, and elements of thinking in the activity (Table I):

TABLE I.

\begin{tabular}{|c|c|c|c|c|c|c|c|c|}
\hline \multirow[t]{2}{*}{ no. } & \multicolumn{2}{|c|}{ Instructions } & \multirow[t]{2}{*}{$\begin{array}{c}\text { Engagem } \\
\text { ent of } \\
\text { senses }\end{array}$} & \multicolumn{4}{|c|}{$\begin{array}{c}\text { Phases of } \\
\text { Kolb model } \\
\text { applied }\end{array}$} & \multirow[t]{2}{*}{$\begin{array}{l}\text { Elements of } \\
\text { thinking in } \\
\text { the activity }\end{array}$} \\
\hline & $\begin{array}{l}\text { Cle } \\
\text { ar }\end{array}$ & $\begin{array}{c}\text { Modul } \\
\text { ar }\end{array}$ & & 1 & 2 & 3 & 4 & \\
\hline 1 & $\rightarrow$ & $\rightarrow$ & $\begin{array}{l}\text { Touch, } \\
\text { sight }\end{array}$ & $\rightarrow$ & $\rightarrow$ & $\mathrm{x}$ & $\mathrm{x}$ & $\begin{array}{l}\text { Reportage } \\
\text { of } \\
\text { observation } \\
\text { only }\end{array}$ \\
\hline 2 & $\rightarrow$ & $\rightarrow$ & $\begin{array}{l}\text { Touch, } \\
\text { sight }\end{array}$ & $\rightarrow$ & $\rightarrow$ & $\rightarrow$ & & $\begin{array}{l}\text { Inferential } \\
\text { thinking }\end{array}$ \\
\hline 3 & $\rightarrow$ & $\mathrm{x}$ & $\begin{array}{l}\text { Touch, } \\
\text { sight }\end{array}$ & $\rightarrow$ & $\rightarrow$ & $\rightarrow$ & $\rightarrow$ & $\begin{array}{l}\text { Inferential } \\
\text { thinking, } \\
\text { prioritizatio } \\
\text { n, rationale, } \\
\text { offering } \\
\text { additional } \\
\text { ideas }\end{array}$ \\
\hline 4 & $\rightarrow$ & $\mathrm{x}$ & $\begin{array}{l}\text { Touch, } \\
\text { sight }\end{array}$ & $\leftrightarrow$ & $\rightarrow$ & $\mathrm{x}$ & $\mathrm{x}$ & $\begin{array}{l}\text { Compariso } \\
\mathrm{n}\end{array}$ \\
\hline 5 & $\rightarrow$ & $\rightarrow$ & Sight & $\rightarrow$ & $\rightarrow$ & $\mathrm{x}$ & $\mathrm{x}$ & $\begin{array}{l}\text { Compariso } \\
\text { n, causal } \\
\text { thinking }\end{array}$ \\
\hline 6 & $\rightarrow$ & $\rightarrow$ & $\begin{array}{l}\text { Touch, } \\
\text { sight }\end{array}$ & $\rightarrow$ & $\rightarrow$ & $\rightarrow$ & $\mathrm{x}$ & $\begin{array}{l}\text { Compariso } \\
\mathrm{n} \text {, causal } \\
\text { thinking }\end{array}$ \\
\hline 7 & $\rightarrow$ & $\rightarrow$ & Sight & $\rightarrow$ & $\rightarrow$ & $\mathrm{x}$ & $\mathrm{x}$ & $\begin{array}{l}\text { Compariso } \\
\mathrm{n} \text {, causal } \\
\text { thinking }\end{array}$ \\
\hline 8 & $\rightarrow$ & $\rightarrow$ & Sight & $\rightarrow$ & $\rightarrow$ & $\rightarrow$ & $\mathrm{x}$ & $\begin{array}{l}\text { Compariso } \\
\mathrm{n}, \\
\text { inferential } \\
\text { thinking }\end{array}$ \\
\hline 9 & $\rightarrow$ & $\Rightarrow$ & Sight & $\rightarrow$ & $\rightarrow$ & $\mathrm{x}$ & $\mathrm{x}$ & $\begin{array}{l}\text { Prioritizatio } \\
\mathrm{n} \text {, rationale }\end{array}$ \\
\hline 10 & $\rightarrow$ & $\rightarrow$ & Sight & $\rightarrow$ & $\mathrm{x}$ & $\rightarrow$ & $\mathrm{x}$ & $\begin{array}{l}\text { Uninterrupt } \\
\text { ed thinking, } \\
\text { drawing } \\
\text { associations }\end{array}$ \\
\hline 11 & $\rightarrow$ & $\rightarrow$ & Sight & $\rightarrow$ & $\rightarrow$ & $\mathrm{x}$ & $\mathrm{x}$ & $\begin{array}{l}\text { Hypothesizi } \\
\text { ng }\end{array}$ \\
\hline 12 & $\rightarrow$ & $\rightarrow$ & $\begin{array}{l}\text { Touch, } \\
\text { sight }\end{array}$ & $\rightarrow$ & $\rightarrow$ & $\rightarrow$ & $\mathrm{x}$ & $\begin{array}{l}\text { Compariso } \\
\mathrm{n} \text {, } \\
\text { inferential } \\
\text { thinking }\end{array}$ \\
\hline 13 & $\rightarrow$ - & $\rightarrow$ & $\begin{array}{l}\text { Touch, } \\
\text { sight }\end{array}$ & $\rightarrow$ & $\mathrm{x}$ & $\rightarrow$ & $\mathrm{x}$ & $\begin{array}{l}\text { Uninterrupt } \\
\text { ed thinking, } \\
\text { identifying }\end{array}$ \\
\hline 14 & $\rightarrow$ & $\rightarrow$ & Sight & $\rightarrow$ & $\mathrm{x}$ & $\rightarrow$ & $\mathrm{x}$ & $\begin{array}{l}\text { Hypothesizi } \\
\text { ng, } \\
\text { comparison }\end{array}$ \\
\hline 15 & $\rightarrow$ & $\mathrm{x}$ & None & $\mathrm{x}$ & $\mathrm{x}$ & $\mathrm{x}$ & $\rightarrow$ & Creativity \\
\hline 16 & $\rightarrow$ & $\rightarrow$ & None & $\mathrm{x}$ & $\mathrm{x}$ & $\mathrm{x}$ & $\mathrm{x}$ & $\begin{array}{l}\text { Hypothesizi } \\
\text { ng }\end{array}$ \\
\hline 17 & $\rightarrow$ - & $\Rightarrow$ & $\begin{array}{l}\text { Touch, } \\
\text { smell }\end{array}$ & 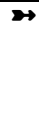 & $\rightarrow$ & $\mathrm{x}$ & $\mathrm{x}$ & $\begin{array}{l}\text { Reportage } \\
\text { of } \\
\text { observation } \\
\text { only }\end{array}$ \\
\hline
\end{tabular}

The table shows that most activities were written clearly and in a modular way. The main sense engaged in most activities was sight (fourteen activities), followed by touch (seven activities). The sense of smell was engaged in only one activity.

Only one activity applied all four phases of Kolb's model. Four activities applied three phases, seven 
activities applied only two phases, and the others applied one or none.

Important thinking and investigative skills that were manifested in the activity are comparison, inferential thinking, causal thinking, and uninterrupted thinking. Several activities related only to observation or observation and hypothesizing and exhibited no meaningful experiential aspect. No tasks that included experimentation for problem-solving were developed.

These findings indicate that the students succeeded in designing experiential learning activities and high order thinking activities. Nevertheless, the activities were limited to the first two stages of Kolb model and to the use of touch and sight mostly. Designing an experiential learning activity that meets all the criteria of a welldesigned activity has been proven to be a complicated and hard task for the students.

\section{DISCUSSION}

The workshop on developing experiential learning activities by means of Smartphones demonstrated that the use of these instruments, at least in the project carried out, didn't reach its full potential. Even though the activities that the students developed did reflect the pedagogical principles of experiential learning, the Smartphone's contribution to learning was inadequate. Since the phone was not used to measure phenomena, access helpful information, and orient students in the garden, it was perceived as unnecessary if not cumbersome. Accordingly, the students did not perceive it as something that would enhance learning motivation; on the contrary: they perceived it as awkward and, as such, a device that makes the learning more complex and less enjoyable.

Additional factors contributed to the deficiency of this activity relative to its planners' expectations; they had to do with the design of, and the participants in, the workshop:

a. The participants were education students specializing in early childhood; this may explain why they did not connect with the activity, which was geared to a different population group.

b. Signal around the garden was impaired by technical difficulties, making it awkward and, at times, impossible to use the Wandering platform to create activities.

c. The activity was planned in a way that overlooked time constraints. The schedule was packed and the students were unable to experience the entire process.

d. In planning the activities, the use of the capabilities of cellular telephones for learning as research, measurement, and documentation tools was underemphasized. Helpful applications were not taught and the students were not instructed to develop activities that would use the telephone as an auxiliary in experiential learning. The Wandering platform did serve as a mobile learning platform, but mainly as a way to access instructions for activity; therefore, its contribution to learning was not considered large. The full abilities of the cellular telephone as a source of supportive information and as a documentation and research tool were not exploited in the activities themselves. Consequently, the contribution of this instrument to the learning process was also perceived as paltry.
Although one cannot define the workshop itself as a smashing success, it did yield several conclusions about the requisite conditions for the successful integration of technology, pedagogy, and learning content:

1. A course that deals with development of learning activities with the help of mobile technology should be based on a lengthier time frame of at least one semester. During this time, students should master the pedagogical basis of experiential study, acquaint themselves with the potential of the smartphone in learning, and develop and carry out learning activities in which smartphones play a role.

2. Learning activity that uses smartphones should take place at a location that has a strong and uninterrupted signal. One has to determine why the students had signal problems in the botanical garden and whether the problem could have been corrected by Wi-Fi in the garden area.

3. The need for the Wandering platform in developing cellphone-enhanced learning processes should be examined. The contribution of this platform to the activity per se was not clear-cut. Wandering did serve as an organizing environment for the development and implementation of mobile learning activities but was perceived as excessively dedicated and inadequately friendly. A trial activity in mobile learning without Wandering, using free and readily available tools, should be conducted, and its outcomes should be tested against those of the activity described above.

4. Thought should be given to improving the model of smartphone use in experiential teaching and to introducing the use of the telephone as a documentation, research, and measurement device in mobile learning activities. This element, absent in the activity described in this study, may significantly improve the perception of the contribution of the cellphone as a meaningful source of support for research processes. This, in turn, may contribute to its perception as a significantly helpful device in experiential learning in the field.

\section{SUMMARY}

The use of smartphones in learning activities in the botanical garden was a groundbreaking activity. Its aim was to reap the benefits that the smartphone can offer without impairing the sensual experience and unmediated learning. This initial attempt to integrate experiential learning and smartphones, however, turned out to be a difficult task. It elicited many conclusions about how the smartphone may be integrated into experiential learning. What remains is to continue the experiment and perform further research to determine the best practices in this mission.

\section{REFERENCES}

[1] G. Merchant. "Mobile practices in everyday life: Popular digital technologies and schooling revisited". British Journal Of Educational Technology,43(5), 2012, pp.770-782. http://dx.doi.org/10.1111/j.1467-8535.2012.01352.x

[2] M. Prensky, "What can you learn from a cell phone? Almost anything!". $\quad$ Innovate 1 (5), http://www.innovateonline.info/index.php?view=article \&id=83

[3] C..Chang, , K Chatterjea, , D. Goh, Y. Theng, E..Lim, , A. Sun, \& Q. Nguyen, "Lessons from Learner Experiences in a Field-Based Inquiry in Geography Using Mobile Devices. International". Research In Geographical And Environmental Education, 21(1), 2012. Pp.41-58. http://dx.doi.org/10.1080/10382046.2012.639155 
PAPER

TEACHING SustainABILITY VIA SMARTPHONE-ENHANCED EXPERIENTIAL LEARNING IN A BOTANICAL GARDEN

[4] P.Mishra \& M. Koehler "Technological pedagogical content knowledge: A framework for teacher knowledge". The Teachers College Record,108(6), 2006.pp.1017-1054. http://dx.doi.org/10.1111/j.1467-9620.2006.00684.x

[5] Sauve', L. "Currents in environmental education: Mapping a complex and evolving pedagogical field". Canadian Journal of Environmental Education, 10, 2005, pp. 11-37.

[6] E. Kals. H. Ittner. "Children's Environmental Identity: Indicators of Behavioral Impacts", in Clayton, S. \& Opotow,S. (Editors) Identity and the Natural Environment, London, England The MIT press Cambridge Massachusetts. 2003. pp.135-157.

[7] PW.Schultz. "New environmental theories: Empathizing with nature: The effects of perspective taking on concern for environmental issues". Journal of Social Issues 56(3). 2000. Pp. 391-406. http://dx.doi.org/10.1111/0022-4537.00174

[8] D. A. Kolb. "Experiential learning: Experience as the source of learning and development". New Jersey: Prentice-Hall, 1984.

[9] N. Orion. "Outdoor learning environment: why and how?" Eureka, 17. 2003. [Hebrew] . Retrieved 30 ${ }^{\text {th }}$ November 2013 from : http://www.matar.ac.il/eureka/newspaper17/article1_5.asp

[10] J. Traxler. "Defining Mobile Learning". Proceedings IADIS International Conference Mobile Learning 2005. Malta, pp 261266.

[11] , M. Sharples, M. Milrad, I.A. Sanchez, and G. Vavoula. "Mobile learning: Small devices, big issues". In N.Balacheff, S. Ludvigsen, T. de Jong, A. Lazonder, S. Barnes, and L. Montandon, ed.Technology enhanced learning: Principles and products, pp.
233-49.Berlin: Springer, 2009. http://dx.doi.org/10.1007/978-14020-9827-7_14

[12] A. Jones, K. Issroff,, E. Scanlon, Clough E. and P. McAndrew. "Using mobile devices for learning in informal settings: is it motivating?", Proceedings of IADIS International Conference Mobile Learning Dublin, IADIS Press, Barcelona, Spain, 2006, pp. 251-5.

[13] C. H. Lai, J. C. Yang, F. C. Chen, C. W. Ho, \& T. W. Chan. "Affordances of mobile technologies for experiential learning: the interplay of technology and pedagogical practices". Journal Of Computer Assisted Learning,23(4), 2007, pp.326-337. http://dx.doi.org/10.1111/j.1365-2729.2007.00237.x

\section{AUTHORS}

H. Meishar-Tal (PhD) is with the Open University of Israel and Oranim college, Israel (e-mail: hagitta@, openu.ac.il).

M. Gross (PhD) is the director of the botanical gardens in Oranim College (e-mail: mukyg@Oranim.ac.il).

This article is an extended and modified version of a paper presented at the International Conference on Interactive Collaborative Learning (ICL2032), held from 25 to 27 September 2013 at Kazan National Research Technological University, in Kazan, Russia. Submitted, 01 December 2013. Published as re-submitted by the authors 05 January 2014. 